\title{
Vegetative Propagation of Desert Saltgrass
}

Rhizomes

\author{
KENNETH A. PAVLICEK, GORDON V. JOHNSON, AND \\ EARL F. ALDON
}

Highlight: Desert saltgrass is a potential candidate for mine spoil-bank revegetation in much of the semiarid West. Laboratory studies showed optimum temperature for growth to be 25 to $30^{\circ} \mathrm{C}$. No clear relationship was found between length of a rhizome section and its capacity to sprout. In desiccation experiments, onenode segments lost water more quickly than did two-node sections. A marked reduction in rhizome sprouting occurred when moisture losses exceeded $35 \%$ of the initial weight. One-node rhizomes stored in polyethylene bags of temperatures of 2 and $10^{\circ} \mathrm{C}$ had sprouting percentages in excess of $65 \%$ after 28 days.

Desert saltgrass (Distichlis stricta (Torr.) Rydb.), a dioecious perennial with stout rhizomes and firm culms and leaves, reproduces itself mainly by rhizome production. Seed production plays a minor role in its pervasiveness.

Because of its reproductive capacity and grazing potential, saltgrass is a candidate for revegetating disturbed areas in the arid Southwest. This paper discusses some aspects of the physiology of rhizomatous growth in desert saltgrass, and some methods of collection and use in revegetation efforts.

The authors are, respectively, graduate student and associate professor of biology, University of New Mexico, Albuquerque; and principal hydrologist, Rocky Mountain Forest and Range Experiment Station, U.S. Department of Agriculture, Forest Service, Albuquerque, in cooperation with University of New Mexico. Station's central headquarters is maintained at Fort Collins in cooperation with Colorado State University.

The research reported here is a contribution to the SEAM program. SEAM, an acronym for Surface Environment and Mining, is a Forest Service program to research, develop, and apply technology that will help maintain a quality environment and other surface values while helping meet the Nation's mineral requirements.

Manuscript received November 12, 1976.

\section{Methods}

Saltgrass rhizomes were freshly collected from a saline site along the Rio Salado near San Ysidro, New Mexico. Only healthy looking specimens, uniform in morphology and size, were used. Samples were washed in tap water, then wrapped in moist paper towels to prevent drying. Rhizomes were planted in moist perlite and incubated for specified periods in darkness to assess sprouting capacity. All sprouting determinations were hased upon the initial number of buds in the sample.

Ten-node sections of rhizomes with the apex removed were collected in the field monthly and prepared for testing rhizome dormancy. Axillary buds per ten-node section were counted prior to incubation. Following a 4-week incubation at $25^{\circ} \mathrm{C}$, the sections were examined for bud growth. Sprouted buds were expressed as a percentage of the initial number of buds present.

Bud sprouting activity was tested with the rhizome apex intact and with the apical segment removed. Ten-node sections were incubated in trays of moist perlite at $25^{\circ} \mathrm{C}$ and harvested after 4 weeks. The sprouting of buds at each nodal position was computed as a percentage. The basic criterion for bud sprouting in this experiment was the development of rhizome buds into shoots with a minimum length of $10 \mathrm{~mm}$.

Maximum bud growth and root production were correlated with section length by sectioning one-, two-, and three-node rhizomes and incubating at $25^{\circ} \mathrm{C}$.

To estimate the influence of temperature on the sprouting of mizomes, one-, two-, and three-node sections, averaging 2.5, 5.5, and $9.5 \mathrm{~cm}$ in length respectively, werc randomly placed in trays of moist perlite and subjected to a $5^{\circ} \mathrm{C}$ increment temperature regime from 10 to $40^{\circ} \mathrm{C}$ for 4 weeks. The number of sprouting rhizomes was expressed as a percentage of the number of samples prepared. 
Table 1. Sprouting capacity and bud extension of 10-node rhizomes with the apical rhizome (apex) intact and removed $(N=10)$.

\begin{tabular}{|c|c|c|c|c|c|c|}
\hline \multirow[b]{2}{*}{$\begin{array}{c}\text { Node } \\
\text { position }\end{array}$} & \multicolumn{3}{|c|}{ Apex intact } & \multicolumn{3}{|c|}{ Apex removed } \\
\hline & $\begin{array}{c}\text { Sprouted buds }{ }^{1} \\
(\%)\end{array}$ & $\begin{array}{c}\text { Mean bud length } \\
\text { (mm) }\end{array}$ & $\begin{array}{l}\mathrm{CV}^{2} \\
(\%)\end{array}$ & $\begin{array}{c}\text { Sprouted buds } \\
(\%) \\
\end{array}$ & $\begin{array}{l}\text { Mean bud length } \\
(\mathrm{mm})\end{array}$ & $\begin{array}{l}\text { CV } \\
(\%)\end{array}$ \\
\hline 1 (apical) & 0.0 & 2.8 & 14 & 77.7 & 25.0 & 14 \\
\hline 2 & 20.0 & 7.7 & 8 & 66.6 & 17.6 & 20 \\
\hline 3 & 44.4 & 9.8 & 14 & 57.1 & 15.3 & 34 \\
\hline 4 & 40.4 & 13.3 & 18 & 75.0 & 25.7 & 26 \\
\hline 5 & 62.5 & 17.3 & 29 & 100.0 & 51.6 & 9 \\
\hline 6 & 88.8 & 32.2 & 17 & 88.8 & 53.7 & 20 \\
\hline 7 & 90.0 & 49.3 & 18 & 100.0 & 70.1 & 14 \\
\hline 8 & 87.5 & 46.7 & 24 & 100.0 & 78.9 & 8 \\
\hline 9 & 100.0 & 76.2 & 5 & 100.0 & 82.9 & 7 \\
\hline 10 (basal) & 100.0 & 73.3 & 7 & 100.0 & 77.2 & 3 \\
\hline
\end{tabular}

'Based upon bud measurement exceeding $10 \mathrm{~mm}$ in length.

${ }^{2} \mathrm{CV}=$ coefficient of variation.

To test the effect of storage on rhizome viability, rhizomes were washed, leaving leaf scales and roots intact, then stored in 4- by 9-inch self-locking sterile polyethylene bags. Five one-node rhizomes were placed in a bag; five bags comprised a treatment group. Samples were stored at temperatures ranging from -10 to $23^{\circ} \mathrm{C}$ for $1,2,3$, or 4 weeks. At weekly intervals, groups were removed from storage, planted in moist perlite, and incubated at $25^{\circ} \mathrm{C}$. Survival, based upon bud sprouting, was evaluated after 28 days.

The effects of desiccation on rhizome viability were determined on one- and two-node rhizome sections. All leaf scales and roots were removed to maintain uniformity of samples. Fresh weights of the mizome sections were recorded prior to placing the rhizomes in open trays and subjecting them to air drying at a constant room temperature of $22^{\circ} \mathrm{C}$ with relative humidity between 45 and $60 \%$. Periods of desiccation ranged from 1 to 24 hours. Following each drying period, mizomes were again weighed and sections were covered with moist perlite and incubated at $25^{\circ} \mathrm{C}$ for 28 days to assess sprouting capacity. Water loss was expressed as a percentage of fresh weight and survival was expressed as the percentage of the sample that produced sprouts.

Effects of osmotic stress were evaluated on one-node rhizomes. Solutions of $\mathrm{NaCl}$, ranging from 0.05 to $0.50 \mathrm{M}$ at $25^{\circ} \mathrm{C}$ and corresponding to osmotic potentials in the range of -2.34 to -22.81 bars, were uscd to create stress treatments (Lang 1967). Rhizomes were placed on cheesecloth which was stretched over a petri dish with a drain hole in the bottom. The dish was enclosed in a larger petri dish containing the $\mathrm{NaCl}$ solution. The cheesecloth acted as a wick keeping the rhizome sections bathed in the solution. This technique was modified from that used by Thomas (1967). After a 3-week incubation period at $25^{\circ} \mathrm{C}$, survival was assessed in terms of root growth and/or bud sprouting.

\section{Results}

\section{Rhizome Dormancy}

Ten-node sections of desert saltgrass rhizomes harvested monthly over a year sprouted satisfactorily when incubated under favorable conditions. Sprouting percentages fluctuated from 55.7 to $74.1 \%$ throughout the year. This variability may be attributed in part to sampling methods, since rhizomes were taken at random.

Generally, viable buds do not all sprout at the same time under field conditions. Since desert saltgrass buds did not show seasonal dormancy, other regulatory factors seem to be involved. The practical implication from these results is that mughly two-thirds of rhizome buds are capable of sprouting and forming shoots in any season.

\section{Influence of Rhizome Apex on Bud Sprouting}

The rhizome apex dominated the axillary buds. The sprouting capacity of buds closest to the apex was suppressed, with the degree of suppression decreasing as the distance from the apex increased. When the apex was removed, proximal bud sprouting increased markedly (Table 1).

Rhizome apex had a highly significant regression effect $(P<.001)$ on bud length. In spite of large differences among individuals, bud length at each node generally increased as distance from the rhizome apex increased (Fig. 1).

On rhizome segments with intact apices, mean bud length increased from 2.8 to $73.3 \mathrm{~mm}$ (Table 1). Mean bud length was usually increased substantially by removal of the apex.

An axillary bud has three possible fates: to remain inhibited under some form of correlative inhibition, to sprout and develop into an aerial shoot, or to sprout and branch into new rhizomes. These data suggest that desert saltgrass rhizomes are under the control of apical dominance.

\section{Section Length}

Neither percentage bud sprouting nor shoot and root length varied appreciably with section length. Thus section length cannot be used as an index in selection for maximum shoot

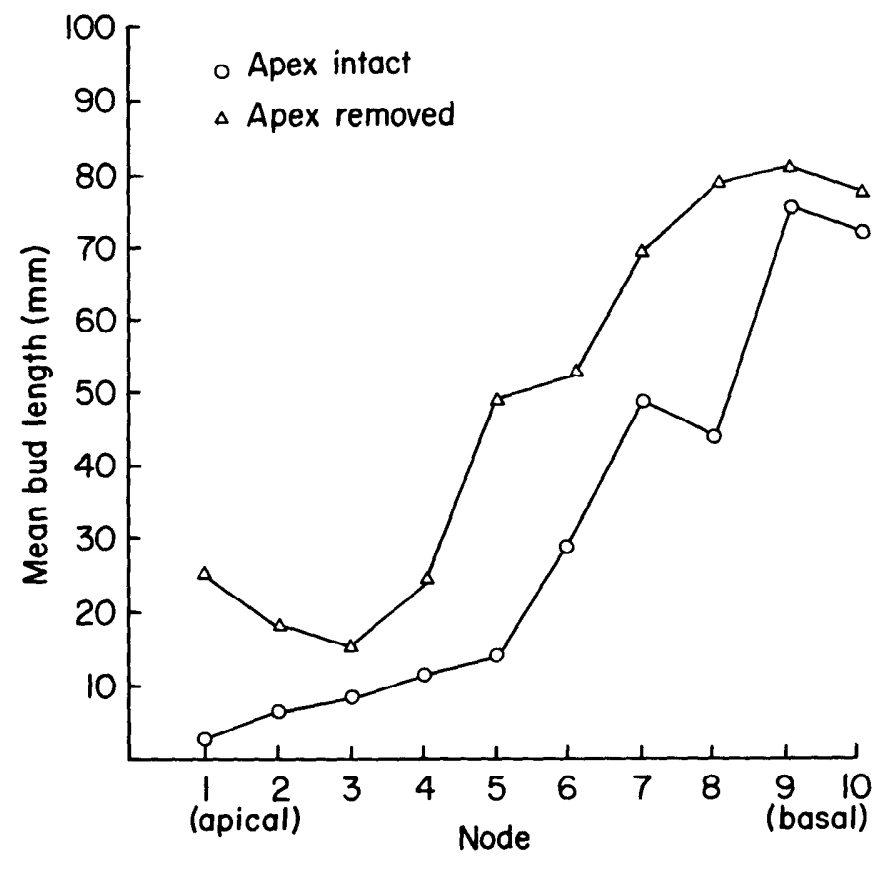

Fig. 1.Mean bud length as a function of node position for rhizomes with apex intact and apex removed. 
Table 2. Effect of section length on bud activity and shoot and root growth in saltgrass rhizomes $(N=10)$.

\begin{tabular}{lccc}
\hline $\begin{array}{l}\text { Rhizome } \\
\text { section }\end{array}$ & $\begin{array}{c}\text { Buds } \\
\text { sprouted } \\
(\%)\end{array}$ & $\begin{array}{c}\text { Mean shoot } \\
\text { length } \\
(\mathrm{mm})\end{array}$ & $\begin{array}{c}\text { Mean root } \\
\text { length } \\
(\mathrm{mm})\end{array}$ \\
\hline I node & $70.0(10)^{1}$ & 36.6 & 41.6 \\
2 node & $73.7(19)$ & 36.4 & 42.4 \\
3 node & $85.7(28)$ & 34.1 & 37.7 \\
\hline
\end{tabular}

${ }^{1}$ Numbers in parentheses indicate the initial number of buds upon which the sprouting percentages are based.

development or root production in desert saltgrass rhizomes (Table 2).

\section{Temperature}

Desert saltgrass rhizome response to temperature was optimum between 25 and $30^{\circ} \mathrm{C}$ (Fig. 2). Three-node rhizome sections had maximum sprouting of $80 \%$ at 25 and $30^{\circ} \mathrm{C}$, while $70 \%$ of the two-node sections sprouted at $30^{\circ} \mathrm{C}$. Sprouting capacity was appreciably diminished at temperatures of $15^{\circ} \mathrm{C}$ and $35-40^{\circ} \mathrm{C}$.

Rhizome sections did not sprout at $10^{\circ} \mathrm{C}$. Similar results were reported by Horowitz (1972a, b) in work with Johnsongrass and Bermudagrass rhizomes. In this investigation, a high percentage of the rhizomes initially incubated at $10^{\circ} \mathrm{C}$ sprouted when incubated at $25^{\circ} \mathrm{C}$. A similar pattern was observed in tests following the storage of rhizomes at $10^{\circ} \mathrm{C}$.

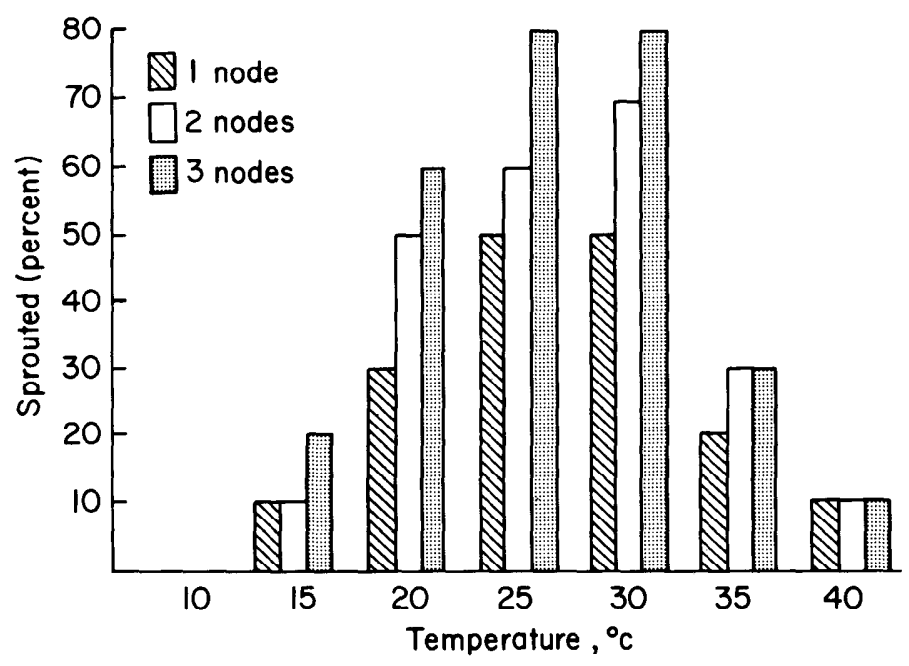

Fig. 2. Sprouting response to temperature.

\section{Storage}

Rhizomes were successfully stored at temperatures of 2 and $10^{\circ} \mathrm{C}$ with humidities from 60 to $75 \%$ for up to 28 days (Table 3).

No buds sprouted when rhizomes were stored at $-10^{\circ} \mathrm{C}$. Segments stored at $23^{\circ} \mathrm{C}$ for 7 days had a sprouting capacity of $76 \%$, but increasing the length of storage to 14 days decreased survival to zero. The decreasing sprouting capacity with storage was attributed to fungal infections.

To alleviate the hazards of desiccation, the undesirable premature sprouting and rooting of rhizomes, and rhizome rot, it is suggested that desert saltgrass rhizomes be stored at a temperature between 2 and $10^{\circ} \mathrm{C}$.
Table 3. Survival of one-node rhizomes effected by storage temperature and time $(N=25)$.

\begin{tabular}{cccccc}
\hline & & \multicolumn{4}{c}{ Survival after (\%) } \\
\cline { 3 - 6 } $\begin{array}{c}\text { Storage } \\
\text { temperature } \\
\left({ }^{\circ} \mathrm{C}\right)\end{array}$ & $\begin{array}{c}\text { Relative humidity } \\
\text { range }(\%)\end{array}$ & $\begin{array}{c}7 \\
\text { days }\end{array}$ & $\begin{array}{c}14 \\
\text { days }\end{array}$ & $\begin{array}{c}21 \\
\text { days }\end{array}$ & $\begin{array}{c}28 \\
\text { days }\end{array}$ \\
\hline-10 & $49-56$ & 0 & 0 & 0 & 0 \\
2 & $60-65$ & 84 & 80 & 68 & 76 \\
10 & $64-75$ & 76 & 72 & 68 & 76 \\
15 & $72-83$ & 68 & 44 & 36 & 0 \\
23 & $80-90$ & 76 & 0 & 0 & 0 \\
\hline
\end{tabular}

\section{Desiccation}

One-node segments of desert saltgrass rhizomes were more adversely affected by water loss than were two-node sections (Table 4), but the magnitude of the difference decreased with time. The viability of rhizomes was generally unaffected by a small initial weight loss, but sprouting capacity decreased as moisture content decreased.

Generally, rhizome sprouting dropped markedly when moisture losses exceeded $35 \%$ of the initial fresh weight. Mean weight loss for one-node rhizomes was $41.1 \%$ after 21 hours as compared to $28.6 \%$ for two-node sections. The sprouting capacities at these times were $0 \%$ and $40 \%$, respectively. In one-node rhizomes, $50 \%$ viability was obtained when the mean weight loss reached approximately $29 \%$. For two-node sections, $50 \%$ viability corresponded to a $21 \%$ weight loss (Table 4 ).

Table 4. Percentage of water loss and buds sprouted for one- and two-node rhizomes as influenced by periods of desiccation $(N=10)$.

\begin{tabular}{ccccc}
\hline & \multicolumn{2}{c}{ One-node rhizomes } & & \multicolumn{2}{c}{ Two-node rhizomes } \\
\cline { 2 - 3 } \cline { 5 - 6 } $\begin{array}{c}\text { Desiccation } \\
\text { period } \\
\text { (hour) }\end{array}$ & $\begin{array}{c}\text { Buds } \\
\text { sprouted } \\
(\%)\end{array}$ & $\begin{array}{c}\text { Mean } \\
\text { water loss } \\
(\%)\end{array}$ & $\begin{array}{c}\text { Buds } \\
\text { sprouted } \\
(\%)\end{array}$ & $\begin{array}{c}\text { Mean } \\
\text { water loss } \\
(\%)\end{array}$ \\
\hline 0 & 100.0 & 0.0 & 100.0 & 0.0 \\
1 & 90.0 & 8.3 & 100.0 & 2.2 \\
2 & 70.0 & 15.7 & 80.0 & 3.2 \\
5 & 70.0 & 22.7 & 90.0 & 8.5 \\
7 & 50.0 & 30.1 & 70.0 & 10.3 \\
10 & 50.0 & 28.8 & 70.0 & 15.7 \\
15 & 20.0 & 35.1 & 50.0 & 21.5 \\
21 & 0.0 & 41.2 & 40.0 & 28.6 \\
24 & 0.0 & 44.0 & 20.0 & 35.6 \\
\hline
\end{tabular}

\section{Osmotic Stress}

Survival ranged from 53.3 to $93.3 \%$ over the osmotic potentials tested (Table 5). The mean values for survival varied with concentration of $\mathrm{NaCl}$ but the differences were nonsignificant.

The data suggest that saltgrass rhizomes can tolerate a wide range of osmotic and water potentials less than -22.8 bars.

Table 5. Survival of one-node saltgrass rhizomes incubated in $\mathrm{NaCl}$ solutions at $25^{\circ} \mathrm{C}(N=15)$.

\begin{tabular}{ccc}
\hline $\begin{array}{c}\text { Concentration } \\
(\mathrm{M})\end{array}$ & $\begin{array}{c}\text { Osmotic potential } \\
\text { (bars) }\end{array}$ & $\begin{array}{c}\text { Survival } \\
(\%)\end{array}$ \\
\hline control & 0.00 & 80.0 \\
0.05 & -2.34 & 93.3 \\
0.10 & -4.62 & 60.0 \\
0.20 & -9.15 & 73.3 \\
0.30 & -13.68 & 73.3 \\
0.40 & -18.23 & 53.3 \\
0.50 & -22.81 & 66.6 \\
\hline
\end{tabular}




\section{Revegetation Guidelines}

Desert saltgrass rhizomes can tolerate a wide range of osmotic potentials, but are sensitive to desiccation. Attempts to establish this species from rhizome sections should be limited to wet, saline areas.

Cutting rhizomes into smaller sections negates the influence of apical dominance and enhances bud sprouting, but planting sections containing more than one node should increase chances of survival. Axillary buds are capable of sprouting at any season to form new shoots and tillers, but growth response is optimum at temperatures of 25 and $30^{\circ} \mathrm{C}$.

Desert saltgrass rhizomes can be stored successfully at low temperatures $\left(2-10^{\circ} \mathrm{C}\right)$ for at least a month. Brought to optimum conditions, they will quickly sprout.

\section{Literature Cited}

Horowitz, M. 1972a. Early development of Johnsongrass. Weed Sci. 20: 271-272

Horowitz, M. 1972b. Development of Cynodon dactylon (L.) Pers. Weed Res. $12: 207-220$

Lang, A. R. G. 1967. Osmotic coefficients and water potentials of sodium chloride solutions from 0 to $40 \mathrm{C}$. Aust. J. Chem. 20:2017-2023.

Thomas, P. E. L. 1967. A rhizome germinating technique for glasshouse propagation. Pest. Artic. C. 13:221-222. 